\title{
Labour productivity and Central American economic integration: the case of El Salvador
}

\author{
Luis René Cáceres ${ }^{1}$
}

\begin{abstract}
This paper seeks to identify the variables that determine labour productivity in El Salvador. The results show that the extreme openness of the Salvadoran economy, combined with the decline in its investment rate since the mid-1990s, have dampened labour productivity growth - as also has happened in other Central American countries. The study also finds that a country's productivity is positively influenced by the vitality of quality employment and investment in neighbouring countries. This article concludes by advocating the restoration of protection to the subregion's production sectors, the promotion of quality education, technology and the acquisition of knowledge and skills.
\end{abstract}

\section{Keywords}

Employment, labour market, labour productivity, measurement, economic growth, investments, economic integration, educational quality, productivity statistics, El Salvador

\section{JEL classification}

D62, E26, F15, F43, O18, R11

\section{Author}

Luis René Cáceres holds a PhD in Economics from the University of Utah (United States).

Email: luisrenecaceres@gmail.com.

\footnotetext{
1 For Raquel Eva Virginia Rosario, my daughter, a tenacious Salvadoran.
} 


\section{Introduction}

Recent studies have noted the persistently declining trend of labour productivity in Latin American countries since the mid-1970s, having grown rapidly between 1950 and 1970. From 2000 to 2015, labour productivity grew by an average of just $0.6 \%$ per year, the lowest rate of all regions in the world. In conjunction with annual employment growth averaging 2.3\%, this explains El Salvador's meagre average economic growth rate of $3 \%$ per year, which is also the lowest of all regions (OECD, 2016; McKinsey, 2017).

The driving role of employment growth is expected to weaken in the future, as it falls to $1.1 \%$ per year, owing to population aging and a declining fertility rate. Unless productivity increases dramatically, economic growth is likely to drop to almost half of its 2000-2015 rate (OECD, 2016; McKinsey, 2017).

This study investigates the determinants of labour productivity in El Salvador. Section II presents a brief review of the recent literature on productivity in Latin American countries, and Section III discusses the data and their statistical properties. Section IV reports the results of the estimation of cointegration equations that express annual productivity growth in El Salvador and other Central American countries in terms of independent variables associated with investment, the labour market, the external sector and the performance of the subregion's other economies. Section $V$ analyses how education quality makes productivity levels interdependent among the Central American countries, and it discusses the implications of this. Section VI sets forth a number of conclusions and recommendations to close the study.

\section{Selected literature review}

Studies on labour productivity in the Latin American countries concur that labour productivity has fallen sharply since the 1970s; but they offer different explanations for this. ${ }^{2}$ The following paragraphs review selected studies of labour productivity in Latin American countries.

Cole, Ohanian and Riascos (2005) performed a production function decomposition exercise to explain economic growth, which found that the size of the labour force relative to the population was not the cause of stagnant per capita income, since this ratio averages around $70 \%$ of its level in the United States. Moreover, the capital/labour ratio has been roughly within $10 \%$ of the United States level. The authors explain that human capital is also not the cause of this stagnation, since, between 1960 and 1990 human capital, measured as the average of school enrolment rates at the primary, secondary and tertiary levels, increased by $19 \%$. Based on these data, they find that total factor productivity (TFP) explains $66 \%$ of the productivity gap.

These authors use data from the 1950s and 1960s to argue that barriers to imports and competition have undermined productivity; yet labour productivity was higher in that period than in the years after the countries implemented drastic import tariff reductions and other measures to stimulate competition.

Daude and Fernández-Arias (2010) used a production function model to analyse Latin America's income per capita gap relative to that of the United States, in terms of gaps in capital per worker, human capital, labour market participation and TFP. The authors show that the contribution of physical capital to the income per capita gap has remained constant average, while the contributions of human capital and labour intensity have declined. Conversely, the contribution of TFP to the income per capita gap doubled over the period, to reach a level of 37\% in 2005.

\footnotetext{
2 Syverson (2011) provides a comprehensive review of the literature on productivity.
} 
Palma (2011) has argued that the sharp drop in productivity since 1980 is explained by the fall in the investment rate, which has been influenced by the collapse of public investment in all countries. This author also notes that another cause of the fall in labour productivity is the shrinking of the manufacturing sector in Latin American countries. One consequence has been a reduction in the percentage of the labour force employed in manufacturing since 1980, in contrast to the growth of employment in this sector that occurred in the previous 30 years. This decline is associated with external openness and other liberal policies in vogue since the 1980s.

The author argues that "together with low rates of investment (including in services and infrastructure) and lack of upward export capacity diversification, there is little doubt that the remarkable neglect of manufacturing since economic reforms lies at the heart of LA's productivity problem, especially its long-term sustainability" (Palma, 2011).

Rodrik and McMillan (2011) developed a model to argue that labour productivity can be increased in two ways: the first is by increasing investments in human capital and technological change in the different sectors, which they call the "within" component of productivity growth; the second is by reallocating labour from low to high productivity sectors, which they refer to as "structural change". The authors emphasize that, between 1950 and 1975, the region experienced rapid productivity growth of $4 \%$, half of which originated in structural change. But since then productivity has trended differently: the variation in productivity in the periods 1950-1975 and 1975-2005 due to change within sectors was the same, $1.8 \%$ per year; but the variation attributable to the structural component turned negative in the second period (-0.2\% per year). They also note that this change occurred despite increased macroeconomic stability and greater openness to foreign trade, together with privatization and more market-oriented policies.

According to these authors, the fall in labour productivity in Latin America is explained by the reallocation of labour from manufacturing to the service sector, which occurred as a consequence of the abrupt opening to international trade. This also led to the contraction of the manufacturing sector, which until then had made a large contribution to productivity. In addition to mentioning the costs that premature deindustrialization impose on economy-wide productivity, the authors argue that "Import competition has caused many industries to contract and release labour to less-productive activities, such as agriculture and the informal sector. One important difference among countries may be the degree to which they are able to manage downsides. A notable feature of Asian-style globalization is that it has had a two-track nature: many import-competing activities have continued to receive support, while new, export-oriented activities were spawned" (Rodrik and McMillan, 2011).

Sosa, Tsounta and Kim (2013) apply the growth accounting method through a production function to determine the causes of economic growth in a sample of Latin American countries in 1980-2012. They find that, between 2003 and 2012, factor accumulation explains 3.75 percentage points of annual economic growth, while TFP explains 0.75 points. The authors conducted exercises to project potential economic growth rates for 2013-2017 and found that the past momentum is unlikely to be sustainable, owing to constraints on increasing labour force participation (including that of women), deficiencies in the quality of education and population ageing.

Cavalcanti Ferreira, de Abreu Pessoa and Veloso (2014) applied a methodology to decompose the sources of growth for 18 Latin American countries on the basis of a production function, in order to quantify the contributions to productivity made by the different inputs. The results showed that TFP grew at an average rate of $0.82 \%$ per year in 1960-1975. However, between 1980 and 2007, it declined at an annual rate of $0.88 \%$. The authors noted the apparent contradiction in the fact that productivity in the region has fallen persistently since the adoption of pro-market policies, after growing vigorously in the 1960s and 1970s under an import substitution regime. 
Cáceres and Cáceres (2017) used a vector autoregressive (VAR) model with panel data from seven Latin American countries to analyse the labour productivity response to shocks to certain variables. The results showed that productivity grew in response to increases in investment, human capital, wages, quality employment and exports; but it declined in response to increases in inequality, the poverty rate, part-time employment and self-employment. The authors explain the negative relation between the Gini coefficient and TFP growth by arguing that inequality fosters self-employment and reduces quality jobs.

Except for the models applied by Rodrik and MacMillan (2011) and Cáceres and Cáceres (2017), those discussed above are based on the measurement of TFP, which raises several questions. First, one must keep in mind the opinion expressed by Solow, and recently emphasized by Syverson (2011), that TFP is the residual of a regression equation and, thus, is a "measure of our ignorance". Moreover, the studies included in the literature review do not explicitly discuss the problems inherent in measuring productivity through TFP. These may be significant given the suboptimal quality of the data used, and, in particular, the existence in Latin America of climate factors that affect GDP and its components, which could have an impact on the residuals of the regression equations.

\section{The model}

An equation for labour productivity based on a Cobb-Douglas production function is derived below. As a starting point it is assumed that gross domestic product, $Y$, is given by:

$$
Y=A K^{a} L^{(1-a)}
$$

In this expression, $A$ represents total factor productivity (TFP), $K$ is the amount of physical capital and $L$ the amount of labour. Dividing through by $L$ gives the following expression for labour productivity:

$\frac{Y}{L}=A\left(\frac{K}{L}\right)^{a}$

A logarithmic transformation of this equation gives: $\log \left(\frac{Y}{L}\right)=\log (A)+\operatorname{aLog}\left(\frac{K}{L}\right)$

Which shows that higher labour productivity results from increases in TFP and in the amount of capital per worker.

If a human capital variable $(H)$ is introduced in the production function, gross domestic product is then given by:

$$
Y=A K^{a} H^{(1-a)}
$$

Expressing human capital as the size of the labour force multiplied by its average education level, $h$, gives:

$$
Y=A K^{a}(h L)^{(1-a)}
$$

Hence, labour productivity can be expressed as:

$$
\frac{Y}{L}=A\left(\frac{K}{L}\right)^{a} h^{(1-a)}
$$

Or, in logarithmic form:

$$
\log \left(\frac{Y}{L}\right)=\log (A)+\operatorname{aLog}\left(\frac{K}{L}\right)+(1-a) \log (h)
$$


Differentiating this last expression shows that the growth rate of labour productivity is determined by the growth rates of TFP, the amount of capital per worker and the level of education in the country.

In estimating this equation, the key issue is how TFP growth is to be measured, for which several authors have studied the identification of potential proxy variables. Isaksson (2007) classified the determinants of TFP under four headings. The first relates to knowledge creation, which is associated with research and development activities, as well as knowledge transmission through foreign trade and foreign direct investment. The second relates to human capital, physical infrastructure and the existence of an efficient financial system. The third covers institutional aspects, integration with the rest of the world and geography. The fourth relates to aspects of competition and the social situation.

Blyde and Fernández-Arias (2006) identify the following variables as important determinants of TFP: average number of years of education, life expectancy at birth, openness to foreign trade, the terms of trade, imports of machinery and equipment, institutional quality, credit to the private sector as a percentage of GDP, government consumption as a share of GDP, the inflation rate and the exchange rate spread in the unofficial foreign exchange market.

The model estimated in this study is based on the Cobb-Douglas production function with human capital, as discussed above, with TFP growth being proxied by some of the variables that have been identified as indirect indicators of labour productivity growth.

\section{The data and their characteristics}

The main data source for this study is the World Bank's World Development Indicators. Unit root tests were performed on the variables; the results of the adjusted Dickey-Fuller test indicated that all were integrated of order 1 at the $5 \%$ level. $^{3}$

The path of labour productivity in El Salvador, ${ }^{4}$ in constant 2010 prices, is shown in figure 1.

Figure 1

El Salvador: labour productivity, 1990-2016

(US\$ million at 2010 prices)

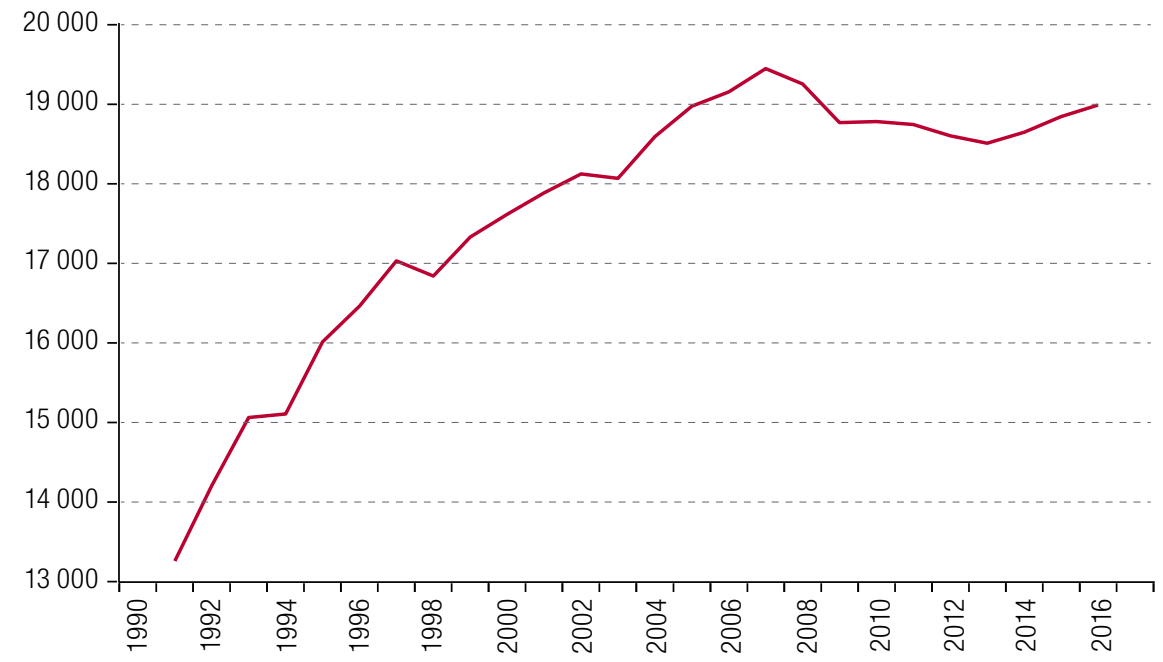

Source: Prepared by the author.

3 The results of the adjusted Dickey-Fuller test, along with the mean values and standard deviations of the variables, are available from the author upon request.

4 The labour productivity data refer to observed employment and are expressed in terms of 2010 prices. 
This variable started to trend down in 2006 before staging a recovery in 2012; but its level in 2016 was still below its 2006 peak. This could be explained by the adverse impact of the 2008-2009 global financial crisis, compounded by the declining trend of national saving and the reduction in import tariffs that occurred from the mid-1980s onwards, which led to deindustrialization (Cáceres, 2017 and 2018a). The extreme openness of the economy has led to lower-quality employment and an increase in self-employment, in other words employment in the informal sector as defined by Loayza (1997).

\section{The model and its estimations}

The model proposed to estimate labour productivity growth is based on a Cobb-Douglas production function with human capital, as specified above. The Rodrik (2013) methodology is also used to estimate labour productivity in Brazil, in which productivity growth increases with investment, labour quality and TFP. Thus, the equations to be estimated reflect the following model:

Annual growth of labour productivity $=\mathrm{F}$ (investment, labour quality indicators, TFP growth).

The role of investment in determining productivity has been supported in several studies, especially Jorgenson, Ho and Stiroh (2004), who showed that physical investment was the main determinant of productivity in the United States. Accordingly, this variable, in both its public and its private versions, will be used in the estimations performed in this study. Labour quality will be measured by the self-employment and quality-employment rates, which Cáceres and Cáceres (2017) found to be important determinants of labour productivity. It is further assumed that TFP growth is associated with the independent variables that various studies have identified as its determinants, as discussed in the foregoing paragraphs.

All of the equations were estimated with data for 1990-2016 using the fully modified least squares methodology, developed by Phillips and Hansen (1990), to account for the fact that some variables were non-stationary and that all variables were endogenous. The first of three sets of estimations to explain El Salvador's labour productivity growth is presented in table 1.

Table 1

El Salvador: variables explaining labour productivity growth, 1992-2016

\begin{tabular}{|c|c|c|c|c|c|}
\hline \multirow{2}{*}{ Independent variables } & \multicolumn{5}{|c|}{ Equations } \\
\hline & (1) & (2) & (3) & (4) & (5) \\
\hline \multirow[t]{2}{*}{ Constante } & -0.0078 & -2.0405 & -0.9760 & 67.8085 & 88.6800 \\
\hline & $(0.22)$ & (3.76) & $(0.40)$ & $(5.45)$ & (6.64) \\
\hline \multirow[t]{2}{*}{ Gini } & -0.3100 & -0.3740 & -0.3893 & -0.8322 & -0.9835 \\
\hline & $(4.21)$ & (3.50) & $(4.83)$ & (10.16) & (10.95) \\
\hline \multirow[t]{2}{*}{ Ipriv } & 1.1000 & 0.6576 & 0.6892 & & \\
\hline & (5.48) & (3.25) & $(4.22)$ & & \\
\hline \multirow[t]{2}{*}{ Ipriv(-2) } & & & & 0.4042 & 0.7006 \\
\hline & & & & $(4.21)$ & (5.67) \\
\hline \multirow[t]{2}{*}{ Ipub(-2) } & 2.0201 & 1.6261 & 0.9859 & 1.3651 & 1.5571 \\
\hline & $(5.20)$ & (3.34) & (2.35) & $(5.46)$ & (5.68) \\
\hline \multirow[t]{2}{*}{ Remesas } & -0.2273 & & & & \\
\hline & $(2.08)$ & & & & \\
\hline \multirow[t]{2}{*}{ Población } & & 0.6101 & & & \\
\hline & & (2.74) & & & \\
\hline \multirow[t]{2}{*}{$\mathrm{TT}$} & & & 0.0826 & & \\
\hline & & & (3.54) & & \\
\hline \multirow[t]{2}{*}{ Tarifa } & & & -0.2658 & & \\
\hline & & & $(2.40)$ & & \\
\hline
\end{tabular}


Table 1 (concluded)

\begin{tabular}{|c|c|c|c|c|c|}
\hline \multirow{2}{*}{ Independent variables } & \multicolumn{5}{|c|}{ Equations } \\
\hline & (1) & (2) & (3) & (4) & (5) \\
\hline \multirow[t]{2}{*}{ Serv } & & & & -0.9248 & -1.2554 \\
\hline & & & & $(5.15)$ & (6.71) \\
\hline \multirow[t]{2}{*}{ Manu } & & & & 0.9756 & 0.8115 \\
\hline & & & & $(10.11)$ & (7.79) \\
\hline \multirow[t]{2}{*}{ Apertura(-1) } & & & & -0.1241 & \\
\hline & & & & (5.32) & \\
\hline \multirow[t]{2}{*}{ Crédito } & & & & 0.1156 & 0.1213 \\
\hline & & & & $(2.20)$ & (2.12) \\
\hline \multirow[t]{2}{*}{ Balanza } & & & & & -0.2071 \\
\hline & & & & & (3.89) \\
\hline R-squared & 0.60 & 0.58 & 0.61 & 0.83 & 0.81 \\
\hline
\end{tabular}

Source: Prepared by the author.

Note: Ipriv: private investment rate; Ipriv(-2): private investment rate with a two-year lag; Ipub(-2): public investment rate with a two-year lag; Remesas: ratio of remittances to GDP; Población: percentage of total population residing in the country's capital; TT: terms of trade index; Tarifa: average tariff on imports; Serv: services sector share of GDP; Manu: manufacturing share of GDP; Apertura(-1): sum of the ratios of exports and imports to GDP with a one-year lag; Crédito: ratio of bank lending to the private sector relative to GDP; Balanza: trade deficit as a percentage of GDP.

Equation (1) in table 1 shows that the coefficient of the Gini variable is negative and highly significant, which indicates that inequality undermines productivity growth. Inequality has been declining in most of the region's countries since the early years of the 2000 decade, which several authors have explained in terms of increases in social spending (González and Martner, 2012). In El Salvador, the Gini coefficient has fallen steadily in recent years, from 46.7 in 2007 to 40.0 in 2016, which has helped prevent further deteriorations in productivity. Cáceres (2017) found that, in Latin American countries, inequality is positively associated with self-employment (in other words precarious employment), while Chong and Gradstein (2004) concluded that inequality led to growth of the informal economy (self-employment), which is likely to diminish productivity.

The coefficient of the private sector investment rate is positive and significant, while that of public investment was only significant when it entered the equation with a two-year lag. This could mean that public investment needs an "incubation" period for its effect on labour productivity growth to be felt. However, the coefficient of public investment is three times greater than that of private investment, which suggests that the argument that the state should be downsized to increase productivity is without merit.

The ratio of remittances to GDP (Remesas) has a negative and significant coefficient, which could reflect the fact that a lack of jobs and quality social services motivates people to migrate. ${ }^{5}$

The percentage of the total population living in the capital city (Población) is included in equation (2) and has a positive and significant coefficient. This variable can be interpreted as an indicator of the agglomeration economies that the capital city offers to firms in terms of facilities for hiring skilled labour and forging complementarity relationships with other firms. A study by Carlino and Voith (1992), for the United States, identified the main determinants of state labour productivity as the corresponding levels of education and population density. Decker, Thompson and Wohar (2009) showed that productivity in these states was mainly determined by the percentage of the state population with a college degree and by the percentage of the population living in metropolitan areas. Florida, Mellander and Stolarik (2016) showed, also for the United States, that firms perform better in metropolitan areas, owing to the abundance of human capital in cities with high population densities.

5 This contrasts with the positive productivity impact that migration has in developed countries: a 1 percentage point increase in the proportion of a country's population that is migrant results, in the long run, in a $2 \%$ increase in that country's per capita growth rate, mainly through productivity growth. See Jaumotte, Koloskova and Saxena (2016). 
Equation (3) includes two additional variables: the terms of trade index (TT) and the average import tariff (Tarifa). Their coefficients are both significant, positive for the former and negative for the latter. The first result is consistent with the literature regarding the important role played by the terms of trade in the business cycle; in contrast, the negative coefficient of the external tariff underscores the finding that trade liberalization has resulted in reductions in labour productivity growth, which is consistent with the results reported by Palma (2011) and by Rodrik and McMillan (2011).

Equations (4) and (5) present the results when the independent variables include some related to the external sector. In these equations, the private investment rate enters with a lag of two years to reduce the high correlation it has with manufacturing activity. The GDP shares of the services sector (Serv) and manufacturing (Manu) display significant coefficients, the former negative and the latter positive. The coefficient of the ratio of bank lending to the private sector relative to GDP is positive and significant. The estimation of equation (4) is particularly important since the coefficient of openness, measured as the sum of the ratios of exports and imports to GDP with a one-year lag (Apertura (-1)) is negative and significant.

In the literature, the openness variable is considered a determinant of economic "efficiency", on the grounds that the higher it is, the less are the "distortions" caused by protection. Yet, far from promoting efficiency, openness has resulted in diminished labour productivity.

Equation (5) introduces the trade deficit relative to GDP (Balanza) as an independent variable; its coefficient is negative and significant.

A large trade deficit would mean that the current account deficit would also tend to be large, implying significant demand for external funding. This could impose a limit on total investment, with adverse consequences for productivity and economic growth. In the Salvadoran economy, this situation becomes critical given its low national saving rate of around 8\% in recent years; so keeping the current account deficit below $4 \%$ requires total investment not to exceed $12 \%$. This provides another explanation for El Salvador's slow economic growth: this cap on the investment rate is 10 percentage points lower than that prevailing in the 1970s, when the import substitution model was in force.

The Gini coefficient is the variable with the highest $t$-statistic in all the equations presented in table 1, which would imply that inequality constitutes the framework through which the other variables affecting productivity interact; and it also highlights the role of inequality in undermining economic efficiency (ECLAC, 2018).

Table 2 presents the results with independent variables that include labour market indicators. Equations (1) and (2) show that the female and male participation rates have negative and significant coefficients. This could be explained by the fact that the Salvadoran labour force mainly works informally in the low-quality services sector, where no special skills or abilities are required. These results should be compared with those reported by Peterson, Mariscal and Ishi (2017) in a study for Canada, which found that the increased labour supply of highly educated women had fuelled productivity growth, for which the existence of childcare networks had played an important role. In addition, Cáceres (2017), using a cross-sectional sample of data from Latin American countries, finds that as per capita social spending increases, the quality employment rate also rises while self-employment declines, with a consequent positive impact on productivity.

In equations (3) and (4) the female and male self-employment rates show negative and positive coefficients, respectively; the former is marginally significant, and the latter is not significant. Equations (5) and (6) show that the coefficients of the female and male industrial employment rates, with lags of one and two years, respectively, are both positive and significant. The coefficient of the second of these rates is larger than that of the first (0.4266, compared to 0.2640), implying that male industrial employment has twice the impact of female employment in that sector, in terms of its contribution to labour productivity growth. This reflects the fact that there are differences between the type of industrial jobs held by women and men, revealing the existence of gender-segregated labour markets and gender discrimination. 
Table 2

El Salvador: variables explaining labour productivity growth rate, including labour market indicators, 1992-2016

\begin{tabular}{|c|c|c|c|c|c|c|}
\hline \multirow{2}{*}{ Independent variables } & \multicolumn{6}{|c|}{ Equations } \\
\hline & (1) & (2) & (1) & (4) & (1) & (6) \\
\hline \multirow[t]{2}{*}{ Constante } & 23.6236 & 37.1976 & -6.4960 & 2.0010 & 0.4638 & -10.3361 \\
\hline & (2.89) & (2.84) & $(1.56)$ & $(0.41)$ & $(0.18)$ & (3.46) \\
\hline \multirow[t]{2}{*}{ Gini } & -0.4050 & -0.4409 & -0.3495 & -0.3742 & -0.5157 & -0.4742 \\
\hline & (4.83) & (6.28) & $(4.54)$ & $(4.35)$ & (5.44) & (4.96) \\
\hline \multirow[t]{2}{*}{ Ipriv } & 0.7771 & 0.6091 & 0.6740 & 0.6371 & 0.5917 & 0.7573 \\
\hline & $(2.16)$ & (4.18) & (4.51) & (3.38) & (3.53) & $(4.54)$ \\
\hline \multirow[t]{2}{*}{ Ipub(-2) } & 0.9365 & 0.9757 & 0.9796 & 0.8996 & 0.9811 & 1.2831 \\
\hline & $(2.15)$ & (2.67) & $(2.55)$ & $(2.00)$ & $(2.38)$ & (3.15) \\
\hline \multirow[t]{2}{*}{$\Pi$} & 0.0595 & 0.1072 & 0.0804 & 0.0860 & 0.0876 & 0.1112 \\
\hline & $(2.20)$ & $(5.09)$ & $(3.74)$ & (3.45) & $(3.80)$ & $(4.28)$ \\
\hline \multirow[t]{2}{*}{ Tarifa } & 0.1411 & 0.3782 & 0.2136 & 0.2829 & 0.2278 & \\
\hline & (1.16) & (3.82) & $(2.00)$ & (2.36) & (2.05) & \\
\hline \multirow[t]{2}{*}{ Participación femenina } & -0.4816 & & & & & \\
\hline & $(3.02)$ & & & & & \\
\hline \multirow[t]{2}{*}{ Participación masculina } & -0.4700 & & & & & \\
\hline & $(2.84)$ & & & & & \\
\hline \multirow[t]{2}{*}{ Auto femenino } & -0.0813 & & & & & \\
\hline & $(1.70)$ & & & & & \\
\hline \multirow[t]{2}{*}{ Auto masculino } & 0.0848 & & & & & \\
\hline & $(0.80)$ & & & & & \\
\hline \multirow[t]{2}{*}{ Industrial femenino (-1) } & 0.2640 & & & & & \\
\hline & $(2.16)$ & & & & & \\
\hline \multirow[t]{2}{*}{ Industrial masculino (-2) } & 0.4266 & & & & & \\
\hline & $(2.91)$ & & & & & \\
\hline R-squared & 0.70 & 0.66 & 0.62 & 0.61 & 0.64 & 0.67 \\
\hline
\end{tabular}

Source: Prepared by the author.

Note: Gini: Gini coefficient; Ipriv: private investment rate; Ipub (-2): public investment rate with two-year lag; $\pi$ : terms of trade index; Tarifa: average tariff applied to imports; Participación femenina: female labour participation rate; Participación masculina: male labour participation rate; Auto femenino: female self-employment rate; Auto masculino: male self-employment rate; Industrial femenino (-1): female industrial employment rate; Industrial masculino (-2): male industrial employment rate.

\section{Labour productivity and Central American economic integration}

Agglomeration economies at the national level provide firms with access to ample supplies of labour and technical services, giving rise to a "pool" of specialized inputs, related either to industrial facilities and equipment or to knowledge. It can also be argued that the Central American countries benefit from regional agglomeration economies, since firms in one country can access the labour and technical services of other countries. ${ }^{6}$ Crespi and others (2008) have presented conclusive evidence that firms obtain knowledge from other firms with which they have frequent contacts, such as producers of their inputs and competitors. In other words, the Central American environment is a place for the acquisition of knowledge and good practices that are available to national firms for selection and implementation. This would increase national labour productivity by more than if firms were to imitate only the good practices of their own country.

\footnotetext{
6 In Central America, the national private sectors keep themselves informed through the Federation of Chambers of Commerce of Central America and the Dominican Republic (FECAMCO), among other channels; and there are several financial and economic management publications with regional coverage.
} 
Figure 2 shows the relationship between Guatemala's female industrial employment rate and El Salvador's labour productivity growth.

Figure 2

Female industrial employment in Guatemala vs. labour productivity growth rates in El Salvador, 1992-2016

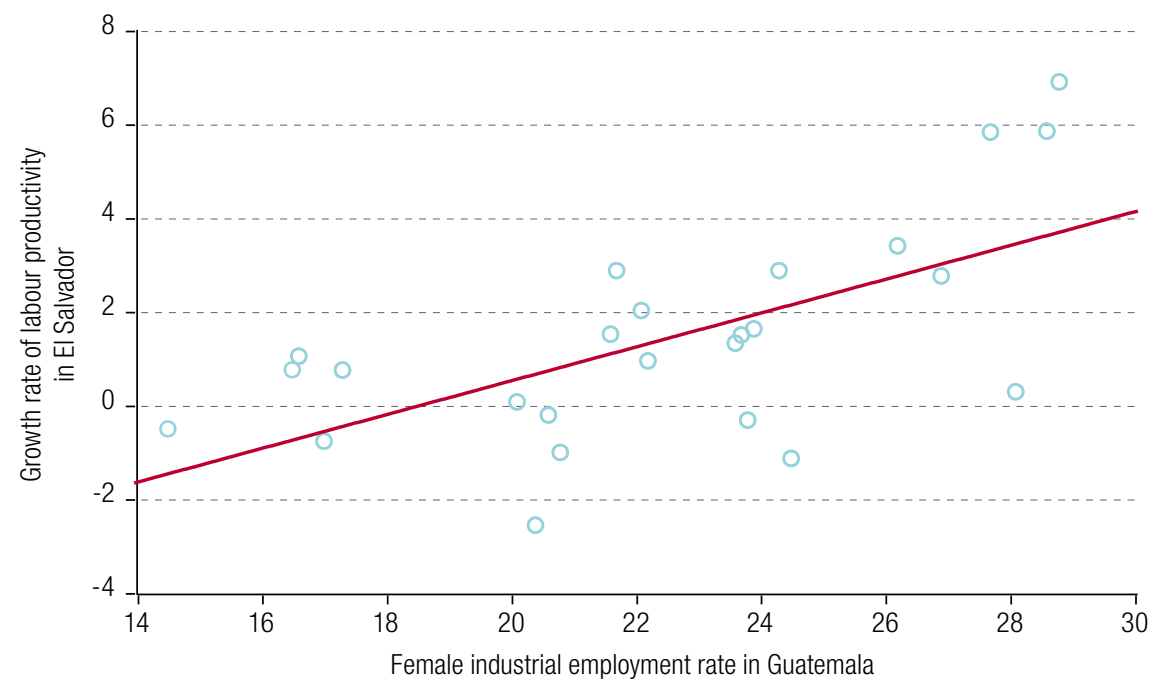

Source: Prepared by the author.

In order to detect the existence of regional agglomeration economies, equations were estimated for labour productivity growth in El Salvador, including among the independent variables those corresponding to Guatemala, Honduras and Costa Rica. These equations also include El Salvador's manufacturing production, to control for the increase in Salvadoran exports to the other countries in response to the increase in investment or the increase in industrial employment in those countries. Thus, the impacts of the coefficients of public and private investment in those countries have been purged from the increase in their aggregate demand.

Table 3 presents the results with variables for Guatemala, Honduras and Costa Rica. Equations (1) and (2) show that private investment in Guatemala with a one-year lag (Guapriinvest(-1)) and public investment in that country with a two-year lag (Guapubinvest(-2)) have positive and significant coefficients. This indicates that the effects of investment in Guatemala spill over to productivity in El Salvador. This could be interpreted as the result of a mechanism whereby Salvadoran firms learn the techniques incorporated in new private investment in Guatemala; another explanation could be that Guatemalan private investment "forces" Salvadoran firms to make greater efforts to increase their productivity and thus be able to respond to Guatemalan competition more effectively.

The positive impact of public investment could be interpreted as a consequence of improved physical infrastructure in Guatemala, resulting from its additional public investment. This would help reduce the cost of transporting goods between countries.

Equation (3) shows that the coefficient of Guatemala's one-year lagged male industrial employment rate (Guaempleoindustrialmasc(-1)) is positive and significant. This could mean that Salvadoran firms recognize that the increase in industrial employment in Guatemala could cause them to lose market share, so they take steps to enhance their productivity. 
Table 3

El Salvador: variables explaining labour productivity growth rate, the role of Central American economic integration

\begin{tabular}{|c|c|c|c|c|c|c|}
\hline \multirow{2}{*}{ Independent variables } & \multicolumn{6}{|c|}{ Equations } \\
\hline & (1) & (2) & (3) & (4) & (5) & (6) \\
\hline \multirow[t]{2}{*}{ Constante } & 9.2031 & 10.2771 & 0.5569 & 6.7234 & 7.2784 & 5.0682 \\
\hline & $(3.10)$ & (3.04) & $(0.14)$ & (2.16) & $(2.56)$ & (1.95) \\
\hline \multirow[t]{2}{*}{ Gini } & -0.5320 & -0.4491 & -0.5463 & -0.5387 & -0.5600 & -0.5631 \\
\hline & $(7.86)$ & $(6.10)$ & (7.27) & (7.30) & $(8.68)$ & (12.96) \\
\hline \multirow[t]{2}{*}{ Ipriv } & & 0.5393 & & & & \\
\hline & & (2.95) & & & & \\
\hline \multirow[t]{2}{*}{ Ipriv(-2) } & 0.5475 & & 0.3314 & 0.5579 & 0.4980 & \\
\hline & $(4.77)$ & & (2.10) & $(4.40)$ & $(4.37)$ & \\
\hline \multirow[t]{2}{*}{ Ipriv(-1) } & & & & & & 0.3886 \\
\hline & & & & & & (3.56) \\
\hline \multirow[t]{2}{*}{ Ipub(-2) } & 1.8616 & 1.8098 & 0.8458 & 0.9550 & 1.5817 & 1.1084 \\
\hline & (6.05) & $(4.35)$ & $(1.82)$ & (2.02) & $(5.30)$ & $(4.87)$ \\
\hline \multirow[t]{2}{*}{ Manu } & 0.6607 & 0.4793 & 1.0677 & 0.8651 & 0.8959 & 0.6500 \\
\hline & $(4.91)$ & $(2.71)$ & (6.41) & $(7.20)$ & $(8.20)$ & (7.54) \\
\hline \multirow[t]{2}{*}{ Apertura } & -0.2003 & -0.1826 & -0.1273 & -0.1910 & -0.1952 & -0.2740 \\
\hline & (7.12) & $(6.04)$ & (3.66) & $(6.43)$ & (7.24) & (11.96) \\
\hline \multirow[t]{2}{*}{ Guapriinvest(-1) } & 0.2413 & & & & & \\
\hline & $(2.88)$ & & & & & \\
\hline \multirow[t]{2}{*}{ Guapubinvest(-2) } & & 0.4725 & & & & \\
\hline & & $(2.02)$ & & & & \\
\hline \multirow[t]{2}{*}{ Guaempeloindustrialmasc(-1) } & & & 0.1904 & & & \\
\hline & & & (2.42) & & & \\
\hline \multirow[t]{2}{*}{ Hopriinv } & & & & 0.0945 & & \\
\hline & & & & (2.66) & & \\
\hline \multirow[t]{2}{*}{ Hoempleoindustrialmasc } & & & & & 0.1128 & \\
\hline & & & & & $(3.64)$ & \\
\hline \multirow[t]{2}{*}{ CRempleoindustrialmasc } & & & & & & 0.7146 \\
\hline & & & & & & (6.66) \\
\hline R-squared & 0.80 & 0.72 & 0.78 & 0.77 & 0.81 & 0.88 \\
\hline
\end{tabular}

Source: Prepared by the author.

Note: Where no country is mentioned, the variables correspond to El Salvador. Ipriv: private investment rate; Ipriv(-2): private investment rate with a two-year lag; Ipriv(-1): private investment rate with a one-year lag; Ipub(-2): public investment rate with a two-year lag; Manu: share of manufacturing in GDP; Apertura: sum of the ratios of exports and imports to GDP; Guapriinvest(-1): Guatemala's private investment rate with one-year lag; Guapubinvest(-2): Guatemala's public investment rate with two-year lag; Guaempleoindustrialmasc(-1): Guatemala's male industrial employment rate with one-year lag; Hopriinv: Honduras' private investment rate; Hoempleoindustrialmasc: Honduras' male industrial employment rate; CRempleoindustrialmasc: Costa Rica's male industrial employment rate.

Equation (4) shows that the private investment rate in Honduras (Hopriinv) has a positive and significant coefficient; in equation (5), the coefficient of the male industrial employment rate of Honduras (Hoempleoindustrialmasc) is also positive and significant; and, in equation (6), the coefficient of Costa Rica's male industrial employment rate (CRempleoindustrialmasc) is positive and significant. However, the coefficients of the female industrial employment rates of Honduras and Costa Rica were found to be non-significant. This could be interpreted as conclusively indicating that cross-country productivity transmission occurs mainly through quality male labour market variables.

The results reported in table 3 show the existence of economies of "emulation" or "replication" at the regional level. It should be noted that the Organization for Economic Cooperation and Development (OECD, 2016) has advised Latin American firms to promote and take advantage of the diffusion of 
knowledge that can come from firms operating at the technological frontier, which are usually multinationals. In Central America, this diffusion of knowledge and its exploitation occurs in firms and gives rise to Central American regional economic spaces.

The results presented in table 3 suggest that a "cold shower" phenomenon (Scitovsky, 1957) could be operating in the Central American countries, whereby competition forces firms to upgrade their procedures and management techniques, in the context of Leibenstein's (1966) X-efficiency theory.

The equations in table 3 show that the independent variables for El Salvador continue to be significant and that the coefficient with the highest $t$-statistic is the Gini index, followed by the share of manufacturing industry in GDP (Manu).

The web of productivity impacts is a result that may be exclusive to countries located in the same geographical region, such as those of Central America. In contrast, a country that chooses unilateral opening could face obstacles such as differences in language and customs, distance, and possible ethnic prejudices, which could frustrate the exchange of techniques and knowledge with the countries from which it imports. Moreover, the latter countries might not be interested in sharing their techniques and good management practices with the importing country. Economic integration has been described as a process of reciprocal exchange of markets, but it could be argued that this reciprocity, which is integration's most valuable feature, goes beyond markets and also involves the sharing of knowledge.

\section{Labour productivity in other Central American countries}

Equations for labour productivity growth were also estimated for two other Central American countries, Costa Rica and Guatemala. ${ }^{7}$ The results are shown in table 4.

Table 4

Costa Rica and Guatemala: variables explaining labour productivity growth rates

\begin{tabular}{lrc}
\hline & Costa Rica & Guatemala \\
\hline Constante & 21.2400 & -0.2704 \\
\cline { 2 - 3 } & $(3.40)$ & $(5.14)$ \\
\hline CRManu & 1.300 & \\
\cline { 2 - 3 } & $(3.62)$ & \\
\hline CRApertura(-1) & -0.1192 & \\
\hline CRTT & $(2.94)$ & \\
\hline ESemploymentwagefemen & -0.1800 & \\
\cline { 2 - 3 } & $(0.47)$ & $(3.95)$ \\
\hline Quali & -0.2800 & -8.1761 \\
\hline GUAPreinv & $(5.14)$ & $(12.88)$ \\
\hline GUEmpleosalariofeme & 0.0050 & 0.6184 \\
\hline & $(5.41)$ & $(5.42)$ \\
\hline
\end{tabular}

7 No labour productivity equations were estimated for Honduras and Nicaragua owing to data limitations. 
Table 4 (concluded)

\begin{tabular}{lcc}
\hline & Costa Rica & Guatemala \\
\hline GUManu(-1) & 9.8160 \\
\cline { 2 - 3 } & & $(9.28)$ \\
\hline GUTax & 3.4090 \\
\hline GUApertura & $(3.16)$ \\
\cline { 2 - 3 } & & -0.9571 \\
\hline R-squared & 0.51 & $(6.28)$ \\
\hline
\end{tabular}

Source: Prepared by the author.

Note: CRManu: share of manufacturing in Costa Rica's GDP; CRApertura(-1): sum of the ratios of exports and imports to Costa Rica's GDP with a one-year lag; CRTarif: average import tariff applied by Costa Rica; CRTT: Costa Rica's terms of trade index; ESempleosalariofemen: El Salvador's female wage and salary employment rate; Cuali: qualitative variable that takes the value of one in 2006 and 2009, when Guatemala's labour productivity fell significantly, and zero in the other years; GUAPreinv: Guatemala's private investment rate; GUEmpleosalariofeme: Guatemala's female wage employment rate; GUManu(-1): share of manufacturing in Guatemala's GDP with a one-year lag; GUTax: ratio of tax revenue to Guatemala's GDP; GUApertura: sum of the ratios of exports and imports to Guatemala's GDP.

In both equations, the respective openness indicator has negative and significant coefficients, while those of the GDP share of manufacturing are positive and significant. El Salvador's female wage earner employment rate has a positive and significant coefficient in both equations. The coefficient of Costa Rica's tariff is not significant, while that of its terms of trade is negative and significant, which can be explained in terms of Funke, Granziera and Iman's (2008) analysis of the impact of the terms of trade on economic growth. In the equation for Guatemala, the qualitative variable Cuali represents the high negative values of labour productivity growth in 2006 and 2009; and its private investment and female wage earner employment rates both display positive and significant coefficients. The coefficient of the ratio of tax revenue to GDP in Guatemala is positive and significant; in other words fiscal effort would contribute to labour productivity growth, especially by supporting public investment and social spending.

\section{Productivity spillovers between Central American countries}

The results reported in tables 3 and 4 mean that one can postulate the existence of economies of integration, that is, economies that arise from an integrated regional economic space. They show that Central American countries "share" their productivity, through the spillovers that occur as a consequence of the growth of investment and the industrial labour force in each country. This concept has not been recognized in the theoretical literature on economic integration. Another implication is that countries that participate in an economic integration mechanism will tend to have higher labour productivity and rates of wage growth than in the absence of integration. This is another issue that has not been recognized in the relevant literature.

In contrast, there is an extensive literature on the productivity spillovers that a foreign firm produces on other firms in the country in which it is located (Syverson, 2011). These spillovers can originate in the purchase of domestic inputs by the foreign firm; in the access gained by domestic firms to modern technology and procedures; and in the movement from the foreign firm to domestic firms of personnel bringing advanced knowledge of managerial and production techniques with them (Gorg and Strobl, 2001 and 2005). This literature is exclusively concerned with the effect of foreign investment on the aggregate domestic productivity of the host country, but the phenomenon of transnational productivity spillovers, as is the case in Central America, has been neglected. 


\section{The interdependence of labour productivity among Central American countries transmitted through education quality}

Hanushek and Woessmann (2007) have demonstrated the important role played by education quality, measured by scores attained on national or international standardized tests, in the behaviour of various economic and social variables. This has also been reported by Cáceres (2018b) in the case of Latin American countries. This section demonstrates that education quality also generates interdependence among Central American countries.

Based on equation (4) in table 3, the variation in El Salvador's labour productivity growth can be expressed in terms of the increase in Honduras' private investment rate:

$D$ (ES productivity growth) $=0.0945 D(\mathrm{HO}$ private investment $)$

Where $D$ represents the first difference of the variable in parentheses.

Using cross-sectional data from Latin American countries, equations were estimated for their private investment as a function of their respective third-grade reading scores, obtained from the Third Regional Comparative and Explanatory Study on Education Quality (TERCE) (UNESCO, 2016), and public spending on education as a percentage of GDP:

$$
\begin{array}{lll}
\text { Privinvest }= & -39.2766+0.0801 \text { (Third grade reading score) } & R^{2}=0.59 \\
& (2.68) & (2.55) \\
\text { Privinvest }= & 5.7559+2.1946 \text { (Public expenditure on education) } & R^{2}=0.71
\end{array}
$$

Thus, the increases in El Salvador's labour productivity growth rates, given increases in Honduras' third grade reading scores and public spending on education are, respectively:

$D$ (ES productivity growth $)=0.0076 D$ (Third grade reading score - Honduras $)$

$D$ (ES productivity growth) $=0.2074 D$ (Public expenditure on education - Honduras)

These two equations indicate that if Honduras' third grade reading score were to increase by 33 percentage points, which is equivalent to attaining the level prevailing in Colombia, El Salvador's labour productivity growth rate would increase by 0.24 of a percentage point. Similarly, increasing public expenditure on education in Honduras by 1 percentage point would increase El Salvador's labour productivity growth rate by 0.21 of a percentage point.

In addition, equation (1) in table 3, which expresses El Salvador's labour productivity growth in terms of a set of independent variables that includes Guatemala's private investment rate, gives rise to the following equations, which express the change in the growth rate of Salvadoran labour productivity in terms of increases in Guatemala's third grade reading score and public spending on education:

$D$ (ES productivity growth) $=0.0193 D$ (Third grade reading score - Guatemala)

$D$ (ES productivity growth) $=0.5300 D$ (Public expenditure on education - Guatemala)

This last equation indicates that if Guatemala's public spending on education were to increase by 1.6 percentage points, in other words to the level prevailing in Ecuador, El Salvador's annual labour productivity growth rate would increase by 0.85 of a point. These results imply that there are regional externalities of labour productivity growth driven by education quality.

Figure 3 shows that education quality spillovers from one Central American country to another fuel synchronous regional productivity growth. 
Figure 3

Economic interdependence through education quality

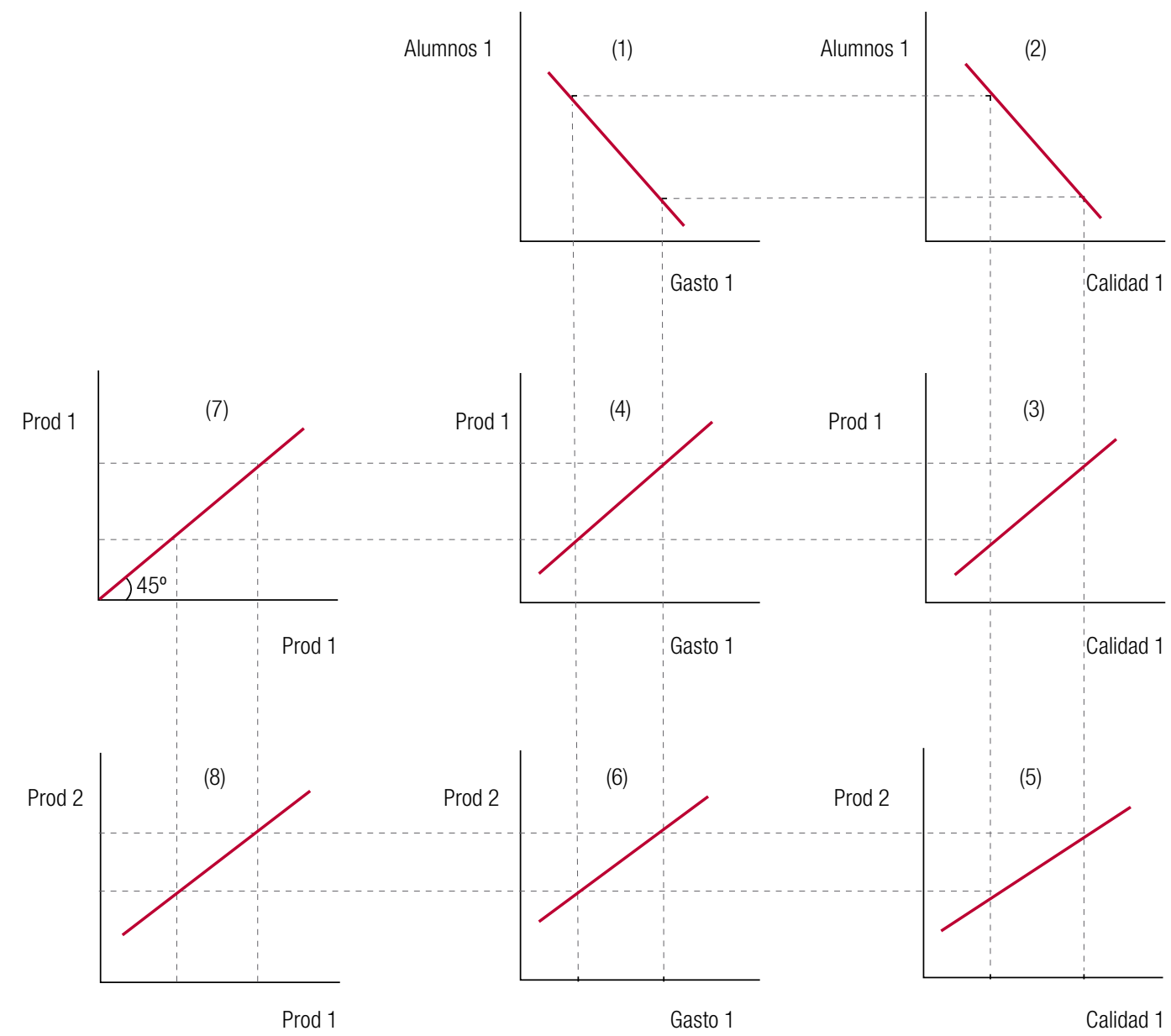

Source: Prepared by the author.

Note: The variables refer to two countries that are members of an integration mechanism, identified as 1 and 2. Alumnos: the number of pupils per teacher in the country; Gasto: public expenditure on education as a percentage of GDP; Calidad: the quality of education as measured by third grade reading scores; Prod: labour productivity.

Quadrant (1) shows the negative relation between education expenditure and the number of pupils per teacher in country 1 , while quadrant (2) indicates that a reduction in the number of pupils per teacher leads to an increase in education quality. ${ }^{8}$ Quadrant (3) shows the positive relation between education quality and labour productivity growth in country 1. Quadrant (3) and quadrant (1) combine to show the positive relation between education expenditure and labour productivity in country 1 that is plotted in quadrant (4). Quadrant (5) shows that education quality in country 1 boosts labour productivity in country 2; and increased spending on education in country 1 leads to increased labour productivity in country 2 (quadrant (6)). Using the 45-degree line of quadrant (7), quadrant (8) reveals a positive relationship between increases in labour productivity in the two countries. In other words, there is harmony or synchrony between national labour productivities within the economic integration zone. This means that, in an integration mechanism such as the Central American one, public expenditure on education would generate much larger increases

\footnotetext{
8 The relationship between the number of students per teacher and scores on international mathematics and reading tests is analysed by Cáceres (2018b).
} 
in labour productivity than would occur in the absence of integration. In other words, integration makes national education spending more "efficient", or more "productive", thanks to regional labour productivity spillovers. ${ }^{9}$

\section{Labour productivity and the distribution of the costs and benefits of integration}

The results reported above have implications for the distribution of the costs and benefits of integration: the relatively more developed member countries could lend to those with low levels of development, for investments that increase education quality. This would lead them to increase their productivity and, hence, their exports, which could result in a more balanced distribution of intra-regional trade. Figure 4, below, analyses the implications of education quality for the distribution of the costs and benefits of integration.

Figure 4

Education quality and the costs and benefits of integration

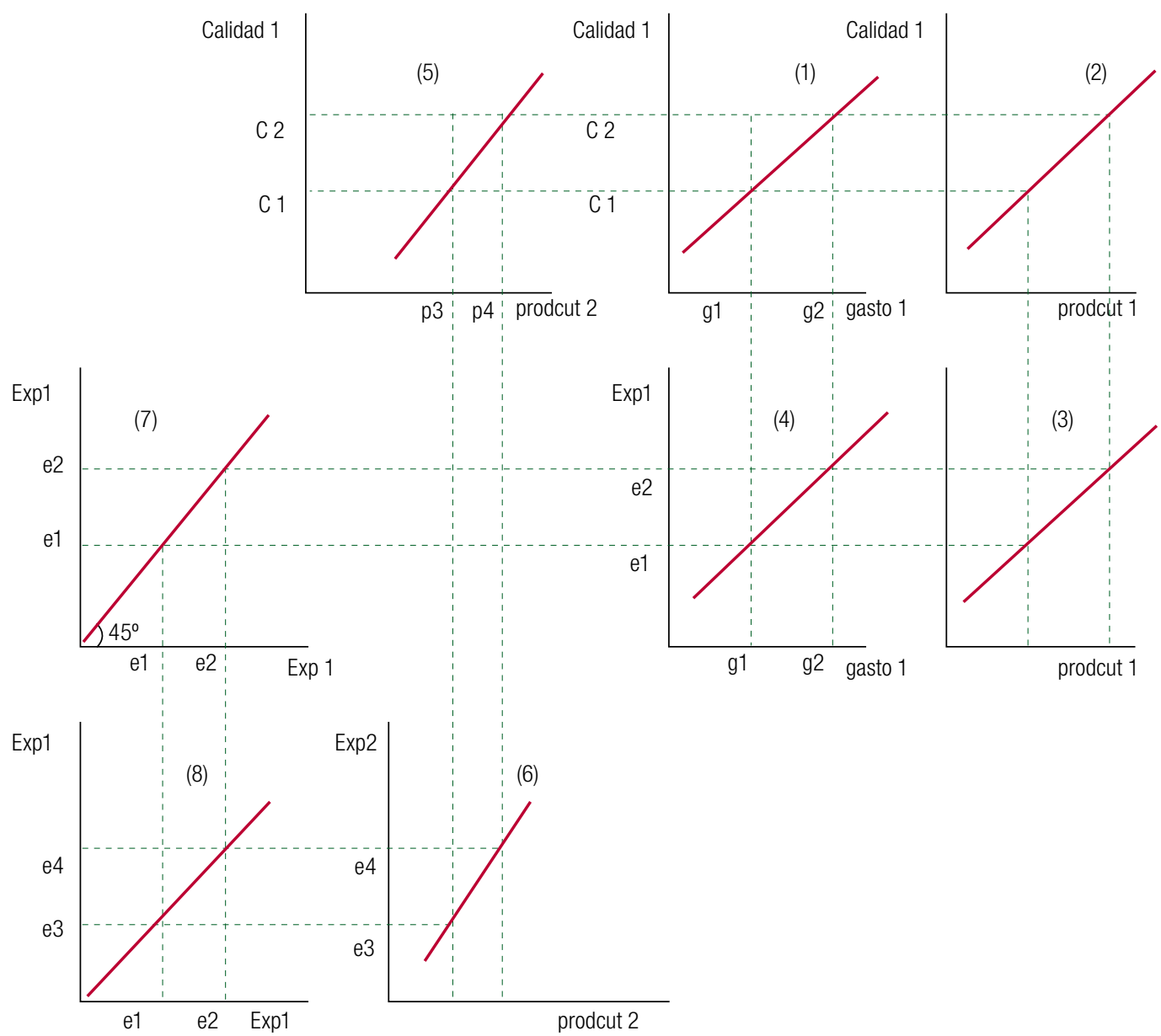

Source: Prepared by the author.

Note: The variables refer to two countries, identified as 1 and 2, that are members of an integration mechanism. Calidad: education quality as measured by third grade reading scores; Prod: labour productivity, Gasto: public expenditure on education as a percentage of GDP; Exp: the country's exports.

9 The specific effect of integration on productivity can be estimated with cross-sectional data in an equation expressing labour productivity growth in terms of certain independent variables, including a dummy variable that takes the value 1 for countries that are members of integration mechanisms. 
Quadrant (1) describes the relation between country 1's education expenditure (Gasto 1) and its education quality (Calidad 1); and quadrant (2) displays the positive association between country 1's education quality and its labour productivity (Prod 1), as demonstrated in Cáceres (2018b). Quadrant (3) expresses the positive relation between country 1's labour productivity and its exports (Exp 1). Quadrants (1) and (3) are combined, in quadrant (4), to infer a positive relation between country 1's education expenditure and its exports.

Suppose that country 1 exports small amounts of goods and services to its partner in the integration programme (country 2) compared to what it imports from it; and, as a result, country 1 expresses discontent with the unbalanced nature of the integration framework.

In response, country 2 grants country 1 an annual transfer that enables country 1 to increase its spending on education from $g 1$ to $g 2$. Consequently, country 1 's education quality increases from $c 1$ to $c 2$ and its productivity rises from $p 1$ to $p 2$; as a result, its exports to country 2 increase from e1 to e2.

It should be noted that the productivity of country 2 rises from $p 3$ to $p 4$ following the increase in country 1's education quality (as shown in quadrant (5) of figure 3); this productivity increase is represented in quadrant (5) of figure 4. Using this quadrant and the 45-degree line in quadrant (7), quadrant (8) shows a positive relationship between the growth of exports in the two countries.

Quadrant (8) shows that the difference between the exports of countries 1 and 2, that is e4-e2, is smaller than it was before (e3-e1); so, the disparity in export performance has been reduced.

The macroeconomic benefits for country 2 are equal to the growth in its exports, in other words e4-e3, multiplied by the Keynesian multiplier, which for Central American countries is around 2.5. The multiplier impact -in other words the increase in output - could exceed the amount of the original transfer, especially considering that, when country 1 attains a certain level of development it will be in a position to assume the additional education expenses that were financed with the transfer it received; and that country 2 will then receive the additional boost to its exports at no cost, which would undoubtedly compensate for its original outlays in transfers to country 1 . There would also be other benefits from having an integration zone with more skilled labour available, which would undoubtedly help to attract additional domestic and foreign investment.

\section{Conclusions}

The results of this study, presented in tables 1,2 and 3 explain the reduction in El Salvador's labour productivity by simultaneous declines in investment and manufacturing industry, and by the loss of good jobs in the manufacturing sector. The negative effects of tariff reductions and large trade deficits have also played a role in this scenario. This result is repeated in the cases of Costa Rica and Guatemala (see table 4). The harmfulness of extreme openness in Central American countries has been partly mitigated, because remittances increase the supply of imported consumer goods, thereby potentially creating a mirage of prosperity. ${ }^{10}$

The productivity decline in El Salvador has been attenuated by the downward trend of income inequality and by positive spillovers of variables from the other Central American countries, such as male industrial employment and investment (see table 3). The existence of these spillovers means that Central American countries act as mutual "shock absorbers", in mitigating negative national productivity trends.

\footnotetext{
10 In some Latin American countries that also implemented "structural" reform programmes in the 1990s, booming prices for their commodities generated an economic bonanza; however, once prices fell back, the countries slipped into recession. This economic contraction could not be countered by the "efficiency" that economic liberalization was supposed to bring to the region's economies.
} 
One conclusion of this study is the desirability of restoring import protection to domestic production in order to foster growth in the manufacturing sector and industrial employment. In 2016, El Salvador and the other Central American countries had import tariffs averaging around 2\%, compared to a Latin American average of $12 \%$. Reducing extreme external openness would contribute towards reindustrialization and, therefore, boost productivity-friendly structural change as labour shifts out of low-quality service sectors and into manufacturing.

In this context, historical data on today's developed countries show that, in their initial stages of development, they did not implement the reforms that Latin American countries carried out in the 1990s; on the contrary, they implemented protectionist practices which persist in various forms to this day. The discourse of economic liberalization has no historical basis, and its theoretical support is questionable at best, as Rodrik (2006) has shown. Moreover, there is evidence that the "efficiency" and "welfare" losses incurred by a country when its trade policies depart from the dictates of comparative advantage are imperceptible; and that countries which diverge from their comparative advantage tend to export manufactured goods (Lectard and Rougier, 2018).

Nonetheless, reinstating protection would be an arduous task in El Salvador and in other countries in the region, since their economies have become import-oriented, and there are vested interests in that status persisting. ${ }^{11}$

Another measure to increase labour productivity in El Salvador is to substantially improve education quality. In this regard, given the productivity spillovers from one country to another, stemming from the improvement of education quality, as shown in previous paragraphs, it would be advisable for Central America to adopt national commitments to achieve specific medium-term goals, related to increased spending on education, a reduction of the number of students per teacher, improvements in the physical infrastructure of schools and technology services, and improvements in the results achieved on national and international standardized tests. This measure would generate larger integration externalities and benefits than if the measures were adopted only at the national level, without regional coordination and commitments. For these purposes, it is important to adopt national fiscal covenants, as part of a regional commitment, which would include a decision to allocate additional funding to education and health, thereby further energizing intra-regional trade and economic growth. It should be noted that in Latin American countries there is a positive relation between productivity and tax revenues relative to GDP (Cáceres, 2018a).

According to the model represented in figure 4, by improving education quality in an integration zone, it is possible to boost the exports of the relatively less developed countries, so that intraregional trade flows would become more balanced; and, in addition, productivity spillovers would lead to an improvement in the export capacity of all member countries. This is a benefit that would not be obtained from unilateral opening.

A notable finding reported by Rodrik and McMillan (2011) is that larger Latin American countries tend to retain their labour force in higher-productivity sectors than smaller countries. The authors argue that, when a regional average that sums up value added and employment in the same sector across countries is computed, giving more weight to larger countries, the negative structural change component turns very slightly positive in Latin America, indicating that labour flows in the larger Latin American countries have not gone as much in the wrong direction as they have in the smaller ones.

\footnotetext{
${ }^{11}$ On the opposition to business and government transparency, competition and investments in human capital, OECD (2016) notes that "Vested interests in the status quo can unduly influence or capture policy making in order to oppose these reforms to maintain their rents. Indeed, some costs can be the result of a conscious design to create rents by capturing regulations and policies. The problem is compounded by the historically high inequality and the concentration of political and economic power in Latin American countries" (p. 11).
} 
This reveals another important role played by regional economic integration: the fact that it boosts national labour productivity as a result of economies of scale derived from the expanded market and productivity spillovers between countries. The share of intra-Latin American exports in the region's total exports declined from $32 \%$ in 1998 to $22 \%$ in $2010 .{ }^{12}$ Hence the imperative need to boost integration as a way to counteract the region's declining productivity trends.

\section{Bibliography}

Blyde, J. and E. Fernández-Arias (2006), "Why does Latin America grow more slowly?", Seminar Papers, No. S-856, Washington, D.C., Inter-American Development Bank (IDB).

Cáceres, L. R. (2018a), "La productividad laboral en América Latina”, Estudios Centroamericanos.

(2018b), "Hechos estilizados sobre la calidad de la educación en América Latina", unpublished.

(2017), Shadow Economies in Latin America, Lambert Academic Publishers.

Cáceres, L. R. and S. Cáceres (2017), "Labor productivity and social policy in Latin America", Journal of Developing Areas, vol. 51, Nashville, Tennessee, State Tennessee University.

Carlino, G. A. and R. Voith (1992), "Accounting for differences in aggregate State productivity", Regional Science and Urban Economics, vol. 22, Amsterdam, Elsevier.

Cavalcanti Ferreira, P., S. de Abreu Pessoa and F. A. Veloso (2014), "On the evolution of total factor productivity in Latin America", Economic Inquiry, vol. 51, New York, John Wiley.

Chong, A. and M. Gradstein (2004), "Inequality, Institutions, and Informality", Working Paper, 5/6, Washington, D.C., Inter-American Development Bank (IDB).

Cole, H. L., L. E. Ohanian and A. Riascos (2005), "Latin America in the rear mirror", Research Department Staff Report, No. 351, Minneapolis, Federal Reserve Bank of Minneapolis.

Crespi, G. and others (2008), "Productivity growth, knowledge flows, and spillovers", Working Paper, No. 13959, Cambridge, Oficina Nacional de Investigaciones Económicas (NBER).

Daude, Ch. and E. Fernandez-Arias (2010), "On the role of productivity and factor accumulation in economic development in Latin America", Working Paper, No. 155, Washington, D.C., Inter-American Development Bank (IDB).

Decker, Ch. S., E. C. Thompson and M. E. Wohar (2009), "Determinants of labor productivity: the changing role of density", Regional Analysis and Policy, vol. 39, Jacksonville, Mid-Continent Regional Science Association.

ECLAC (Economic Commission for Latin America and the Caribbean) (2018), La ineficiencia de la desigualdad (LC/SES.37/3-P), Santiago, May.

Florida, R., Ch. Mellander and K. Stolarick (2016), "Human Capital in Cities and Suburbs", Annals of Regional Science, vol. 57, Springer.

Funke, N., E. Granziera and P. Iman (2008), "Terms of trade shocks and economic recovery", Working Paper, No. 08/36, Washington, D.C., Fondo Monetario Internacional (FMI).

González, I. and R. Martner (2012), "Overcoming the 'empty box syndrome'. Determinants of income distribution in Latin America", CEPAL Review, No. 108 (LC/G.2549-P), Santiago, Economic Commission for Latin America and the Caribbean (ECLAC).

Gorg, H. and E. Strobl (2005), "Spillovers from foreign firms through worker productivity: an emprirical investigation", The Scandinavian Journal of Economics, vol. 107, Wiley.

(2001), "Multinational companies and productivity spillovers: a meta analysis", The Economic Journal, vol. 111, Wiley.

Hanushek, E. A. and L. Woessmann (2007), Education Quality and Economic Growth, Washington, D.C., World Bank.

Isaksson, A. (2007), "Determinants of total factor productivity: a literature review", Research and Statistics Branch Staff Working Paper, No. 02/2007, Vienna, United Nations Industrial Development Organization (UNIDO).

Jaumotte, F., K. Koloskova and S. C. Saxena (2016), "Impacto of migration on income levels in advanced economies", Spillover Notes, No. 8, Washington, D.C., Fondo Monetario Internacional (FMI).

\footnotetext{
12 The very high labour productivity of member countries of the Association of Southeast Asian Nations (ASEAN) could be related to the fact that $50 \%$ of their total external trade takes place within the Association.
} 
Jorgenson, Dale W., Mun S. Ho and Kevin J. Stiroh (2004), "Will the U.S. productive resurgence continue?", Current Issues in Economics and Finance, vol. 10, New York, Federal Reserve Bank of New York.

Lectard, P. and E. Rougier (2018), "Can developing countries gain from defying comparative advantage? distance to comparative advantage, export diversification and sophistication, and the dynamics of specialization", World Development, vol. 102, Amsterdam, Elsevier.

Leibenstein, H. (1966), "Allocative efficiency vs X efficiency", American Economic Review, vol. 56, Nashville, American Economic Association.

Loayza, N. (1997), "The economics of the informal sector. A simple model and some empirical evidence from Latin America", Working Paper, No. 1727, Washington, D.C., Banco Mundial.

Mckinsey Global Institute (2017), "Where will Latin America's growth come from?" [online] http://www. fundacionmicrofinanzasbbva.org/revistaprogreso/en/where-will-latin-americas-growth-come-from/.

OECD (Organization for Economic Cooperation and Development) (2016), "Promoting productivity for inclusive growth in Latin America", Better Policies Series, Paris.

Palma, J. G. (2011), "Why has productivity growth stagnated in most Latin American countries since the neo-liberal reforms?", Cambridge Working Papers in Economics (CWPE), No. 1030, Cambridge University.

Peterson, B., R. Mariscal and K. Ishi (2017), "Women are key for future growth: evidence from Canada", IMF Working Paper, No. 17/166, Washington, D.C., International Monetary Fund (IMF).

Phillips, P. C. B. and B. E. Hansen (1990), "Statistical inference in instrumental variables regressions with I(1) processes", Review of Economic Studies, vol. 57, Oxford, Oxford University Press.

Rodrik, D. (2013), "Productivity growth: lessons for Brazil from other countries" [online] https://drodrik.scholar. harvard.edu/files/dani-rodrik/files/productivity-growth-lessons-for-brazil-from-other-countries.pdf. (2006), "Goodbye Washington Consensus, hello Washington confusion", Journal of Economic Literature, vol. 44, Nashville, American Economic Association.

Rodrik, D. and M. McMillan (2011), "Globalization, structural change and productivity growth", Working Paper, No. 17143, Cambridge, National Bureau of Economic Research (NBER).

Scitovsky, T. (1957), Economic Theory and Western European Integration, London, Allen \& Unwin.

Sosa, S., E. Tsounta and H. S. Kim (2013), "Is the growth momentum in Latin America sustainable?", Working Paper, No. 13/109, Washington, D.C., International Monetary Fund (IMF).

Syverson, Ch. (2011), "What determines productivity?", Journal of Economic Literature, vol. 49, Nashville, American Economic Association.

UNESCO (United Nations Educational, Scientific and Cultural Organization) (2016), Reporte técnico. Tercer Estudio Regional Comparativo y Explicativo (TERCE), Santiago. 